\title{
ARTIGO
}

CO https://doi.org/10.22481/praxisedu.v15i36.5900

\section{"BLOSSOMING COMPLEXITY" OF NATIONAL WORLD PERCEPTION AND A GLOBAL DIGITAL SHIFT: CONCEPTUAL AND METHODOLOGICAL ANALYSIS}

\author{
“COMPLEJIDAD FLORECIENTE” DE LA PERCEPCIÓN MUNDIAL NACIONAL Y UN \\ CAMBIO DIGITAL GLOBAL: ANÁLISIS CONCEPTUAL Y METODOLÓGICO
}
“COMPLEXIDADE FLORESCENTE” DA PERCEPÇÃO MUNDIAL NACIONAL E UMA MUDANÇA DIGITAL GLOBAL: ANÁLISE CONCEITUAL E METODOLÓGICA

Tatiana G. Leshkevich

Southern Federal University, Rostov-on-Don - Russia

Marina A. Nikulina

All-Russian State University of, Rostov-on-Don - Russia

Bika B. Dzhamalova

All-Russian State University of Justice, Makhachkala - Russia

Pari G. Shuaipova

All-Russian State University of Justice, Rostov-on-Don - Russia

\begin{abstract}
The article is devoted to identifying the role and importance of the national world perception in the context of the priorities of the multipolar world in the modern digital era. The main goal of the article is to analyze the status of national philosophy in the era of global transformations. The authors draw attention to a number of interrelated conceptual and methodological problems. The methodological strategy involves the principle of social and cultural determination, activity approach, "enactivism. In the article, the authors give the analysis of the hypotheses, suggesting that the basic programs of human behavior are reflected in the plots of works of fiction through the artistic images, which allows to enter the inner laboratory of the human mentality.
\end{abstract}

Keywords: Worldview; Globalization; Digital era; "Enactivism"; Analogy

Resumen: El artículo está dedicado a identificar el papel y la importancia de la percepción nacional del mundo en el contexto de las prioridades del mundo multipolar en la era digital moderna. El objetivo principal del artículo es analizar el estado de la filosofía nacional en la era de las transformaciones globales. Los autores llaman la atención sobre una serie de 
problemas conceptuales y metodológicos interrelacionados. La estrategia metodológica implica el principio de determinación social y cultural, enfoque de actividad, "enactivismo". En el artículo, los autores analizan las hipótesis, sugiriendo que los programas básicos del comportamiento humano se reflejan en las tramas de obras de ficción a través de las imágenes artísticas, lo que permite ingresar al laboratorio interno de la mentalidad humana.

Palabras clave: Cosmovisión; Globalización; Era digital; "Enactivismo"; Analogía

Resumo: O artigo é dedicado à identificação do papel e da importância da percepção do mundo nacional no contexto das prioridades do mundo multipolar na era digital moderna. $\mathrm{O}$ principal objetivo do artigo é analisar o status da filosofia nacional na era das transformações globais. Os autores chamam a atenção para uma série de problemas conceituais e metodológicos inter-relacionados. A estratégia metodológica envolve o princípio da determinação social e cultural, abordagem da atividade, "enativismo". No artigo, os autores fazem a análise das hipóteses, sugerindo que os programas básicos do comportamento humano são refletidos nas tramas de obras de ficção por meio das imagens artísticas, o que permite entrar no laboratório interno da mentalidade humana.

Palavras-chave: Visão de mundo; Globalização; Era digital; "Enativismo"; Analogia

\section{Introduction}

Understanding the achievements of national philosophy in a global world that has entered the digital era is a responsible and timely task. In modern conditions, the idea of a multipolar world and based on this idea different configuration of prospects for mutual understanding and cooperation are gaining more resonance. The conclusion that specific and very different national images of the world coexist in the global geopolitical space is not new. Such thoughts can be found in the works of N.A. Berdyaev (2007), who spoke about "cosmopsycho-logos" and underlined the fact that "man enters humanity through the national individuality, as a national man, as a Russian, a Frenchman, a German or an Englishman”. There are works by G.V. Plekhanov (1956), whose concept was later called "geographical materialism". This idea is vividly carried out by G. Gachev (1988), with his explanation that the landscape of the country sets not only the conditions of life, but also the features of mentality, character, life practices. The recognition of the identity of the national worldview, which incorporates the specific features of the human attitude to vital events, means recognition of a diverse multipolar world. 
It has become common to claim that the global world forms a single world space in which information, goods and capital move freely. However, a more significant conclusion, in our opinion, is that the uniqueness of places and the specialness of people living in this space should be interpreted by modern researchers as an "immune system", without which the social organism cannot exist and develop. The modern world is interesting because it has many faces, different original cultures coexist in it, and the whole symphonism of the world perception, "everything creative in culture, according to the conclusions of N.A. Berdyaev (2007), has the stamp of national genius".

We emphasize that the identity of the world perception is expressed through a set of assessments and preferences; it contains significant purposeful and meaningful claims, which are accompanied by emotional and intellectual experiences. It is the specificity of the national worldview that determines discursive, symbolic and even body practices, and, therefore, legitimizes the ways of self-representation of a person in all spheres of activity. There are motivating meanings and behavioral strategies in it. They are presented in a minimized form. As it was correctly noted by researchers, "the national idea is an idea that has gripped our thinking, dominate our beliefs and to which our mind attach our conscience - these are those ties from which you cannot escape without ripping your heart" (Abasov, 2015). We also think that the national idea has a significant energy force, which is involved in the formation of the project of the future and captures the historical challenges of the time.

In this context, the role of philosophy as an "epoch grasped in thoughts", which includes images of the national worldview, is of particular importance. Since the global world demonstrates a technological turn and digitalization leading to unification, the main purpose of the article is to analyze the status and priorities of the national philosophy in the era of global transformations. In this regard, it is necessary to pay attention to a number of interrelated problems of conceptual and methodological nature.

\section{Methodological Framework}

The methodological bases of this research relies on the works of Russian and Western researchers, including works of N.A. Berdyaev (2007), G. Gachev, A.N (1988). Chumakov (2014), K. Mainzer (2007), R. Robertson (1995), P. Ricker (2008) and others. In our opinion, the most significant conceptual and methodological objectives of the study include the following. Firstly, any national philosophy has always been aimed not only at 
describing the identity of "attitude to the world as a whole and understanding the place of a man in it", but also to identify the underlying dialectical contradictions of development.

Secondly, Russian philosophical thoughts have always been distinguished by the tendency to reflexive assessment of anthropological consequences caused by rapid development as it is and technological development in particular (Leshkevich, 2017a). The call for social and humanitarian reflection and value-semantic attitude to the events in an explicit or implicit form was the main prerequisite of domestic research.

Thirdly, the leading methodological strategy of Russian philosophy is recognized as the principle of socio-cultural determination, indicating the decisive importance of surrounding circumstances, binding to the real socio-cultural landscape. In addition to it, the activity approach, which is significant for the national humanitarian thought, emphasizes the human desire for self-realization and the embodiment of the abilities. The activity approach will be developed in the innovative concept "enactivism", which focuses on the effect of "involvement of the system in the environment" and their mutual influence. This refers to the situation when a person in the process of self-realization, striving to achieve the goal, modifies himself and the configuration of the existing reality. Enactivism shows how valuesemantic norms can change under the influence of the subject, which changes external circumstances. The concept of enactivism is aimed at "grasping", i.e. reflecting the process of restructuring of semantic regulations, as a result of external circumstances changes made by the subject.

A significant heuristic potential has a method of analogies, revealing the relationship of similarity and a certain proportionality between different events and processes. The analogy of attribution (i.e. inherent qualities) is especially illustrative. In this analogy one and the same property becomes a unifying basis linking different phenomena and subject areas. For example, "healthy lifestyle" - "healthy body" - "healthy society". Moreover, if a strict analogy points to the need for portable evidence of similarity, the fuzzy analogy allows for a certain problem and the probability of the unification processes on the basis of their similarities.

Fourthly, due to the fact that modern technologies, having a kind of "acceleration effect", bring significant dynamics to the development process and color social reality with tones of instability, the problem of uncertainty in the ontological, geopolitical and information and communication keys becomes particularly acute. Today, more than ever, it is felt that the future is the "Great $\mathrm{X}$ " in our lives, and people are forced to make many key decisions in the 
face of uncertainty. The man of the digital era is in a difficult situation not only before the long-term, but also before the medium-term forecast, which certainly affects the models of his behavior.

Fifthly, due to the fact that the modern era has significantly complicated the choice of life strategies of contemporaries, researchers-methodologists define "complexity" as the dominant trend that characterizes not only the cutting edge of science, but also the era itself (Mainzer, 2007). Everywhere fixed and defining the spirit of the XXI century complexity is associated with a variety of processes and forms taking place in reality, and with the subjective plan of the world, fueled by diverse energies and motivations. Increasingly, the modern subject is unable to explain what is happening in a "consistent way", to comprehend it taking into account the cause-and-effect relationships in the "human dimension". The kaleidoscope of rapid changes intensifies the search for the basic programs of human existence. In this context, the question: how to change the configuration of perception of the world under the influence of global transformations of the new digital era with their megatrend to unification is relevant and burning.

\section{Results And Discussion}

\section{Analogy as a Tool for Studying the National Specifics of Worldview}

In the analysis of the specifics of the national worldview in its interaction with the trends of the digital world, in our opinion, it is effective to use three analogies. The first indicates that in a global world, modern humanity appears as a united by a network of interactions integral system, and that new sociality is largely the "Sociality of Network", which is characterized by the phenomenon of network assistance. Here the ratio of national and international can be interpreted as a kind of "intellectual hospitality". A big role is played by the so-called "significant Others", acting as a "challenge" and encouraging growth. At the same time, the national image of the world is imbued with stable stereotypes. A person of one or another ethnicity perceives the world taking into account the existing personal constructs. After all, the national feeling is absorbed "with mother's milk", it "does not migrate like nomads". National philosophy, expressing the identity of the nation, incorporates common sense and folk wisdom, genetic memory and psycho-mental attitudes, ethnic values and socio- 
historical models and patterns of existence. The specificity of national philosophy retains its representativeness even in the "new network sociality".

The national type of worldview by the very fact of its existence demonstrates the dialectical connection of the individual, the special and the general. Russian, Chinese, German, French and other types of philosophical understanding of the world do not lose their importance. They have their intellectual biography, influence the formation of selfconsciousness. At the same time it is important that national philosophies have never been at war, they have always coexisted in dialogue, decorating the landscape of philosophical wisdom with their diversity, strengthening its conceptual foundations. So, if philosophy, according to the century tradition, has always relied on the mind, and in the Russian worldview there was a strong idea of unity, the Kazakh philosophical thoughts very convincingly introduced the concept of "conscientious mind" and pointed out that the mind should be spiritualized and should have spiritual and practical nature (Barlibaeva, 2018). Not of less interest is the supplement of existential understanding to the epistemological dimension of truth within the framework of the Dagestan Sufism. This existential understanding points to "no hiddenness and non-concealment" of truth (Bilalov, 2012). Partnership, intellectual dialogue, openness are able to effectively realize themselves in the new Sociality of the Network, despite its virtual, simulation effects.

The second analogy is based on the identification of society with the whole organism, in which the national philosophy performs the functions of the "immune system". It is a kind of protective shell that preserves mental attitudes, original cultural practices. National philosophy includes a system of meanings aimed at the reproduction of self-identity. The peculiarity is that the national things need a legitimate, recognized by all registration and status. It is not by chance that the concept of "glocalization" (Robertson, 1995) appeared, which is an alternative to globalization. Glocalization emphasizes the value of self-expression, recognition of one's own originality, historical and cultural capital of the national worldview (Leshkevich, 2011). In XXI the dichotomy "globalization-glocalization" points to the confrontation of the so-called "universalists" and "originalists". Familiarization with the world of high speeds and high technologies is regarded as an advantage, but the loss of identity and value of local cultures is equivalent to the loss of the immune system.

The advantage of the third analogy, which points to the specificity of the "granular medium", is that it reveals the presence of identification granules and the possibility of their dissolution in collision with the environment. And if national philosophy is aimed at 
recreating the experience of being in the palette of national worldview, globalization is a "cracking" of local cultures, a kind of "drift" of identity (Leshkevich, 2017b). Although the attitude to globalization is still ambiguous (Chumakov, 2014), it is obvious that under its influence the life worlds of people are significantly transformed. "Waves of globalization" with their unifying impact dissolve the "granules" of national identity, changing the priorities of modern existence. In fairness, it should be noted that sometimes the current state is referred to as a post-national world, and the concept of national is considered outdated due to largescale migrations.

In the context of conceptual and methodological analysis, the hypothesis that the existing basic programs (patterns) of human behavior are reflected in the subjects of works of art is of particular interest. The richest treasury of art helps to enter the inner laboratory of the human mentality from the side of the art work. Diverse programs of human existence are embodied through artistic images. Artistic image, as we know, has the advantage that it has a powerful resource of emotional argumentation, introducing into the consciousness of the individual norms and rules that cannot be justified logically. It incorporates the architectonics of the ethnos, the specific features of the development of the world, the skills and habits peculiar to this environment, customs, mores, attitudes and prejudices. Empathy with the fate of the characters contributes to personal involvement in the event reality and the universe of human relations, reflected in the artistic language. P. Riker, in his own way comprehending the problem of originality of a personal worldview, came to the conclusion that it cannot be solved outside the "narrative identity" (Ricker, 2008). If the existence is associated with lack of opportunities to freely and openly communicate; if the possibility of action is eliminated, if there is a ban on the own choices and decisions; if a person is forced to live in conditions of secrecy and the inability to speak about himself, all of this plunges a man into the abyss of true misery.

If one agrees with these conclusions, it is necessary to distinguish the intellectualconceptual and emotional components of the worldview. The intellectual layer of worldview is based on the current picture of the world with its laws, that is why it acquires sufficient stability and can manifest the properties of supra-individual character. In other words, it is usually presented in the form of universally valid, logically justified attitudes and is covered by the concept "worldview". The intellectual and conceptual segment of the worldview is often fostered by the dominant ideology and includes expectations of the "order of the 
universe", the installation on a certain regularity and lawfulness. It should be noted that this is a sufficiently predictable and predetermined level of worldview.

In contrast, the emotional component of the worldview, including a variety of feelings and moods, is very dependent on the motivational sphere and largely spontaneous. Its specificity is reflected in the concepts of "world outlook", "perception of the world", which, having an affective emotional coloring, can be very mobile and to a certain extent subjective and biased. In general, the worldview system, based on cognitive and psycho-mental mechanisms, includes world understanding, world perception and world attitude. Its effective component becomes a set of beliefs of the subject, producing certain actions and actions. Therefore, it is extremely important to form a system of worldviews, both taking into account the logical and conceptual segment, and capturing the sphere of emotional impact. For it is the worldview that leads a man and humanity to self-expression.

In this respect, the significance of genuine art is that it offers a "supra-empirical translation" of human experience, enriches a man and saturates his life world with meaningful attitudes. A man, within the limits of his finite existence, is incapable of surviving the vital collisions which the human race faces as a whole. The art reproduces numerous dramas and collisions, tragic, comic, heroic and lyrical events, experienced and taking place throughout the multiple centuries history of mankind. In figurative and artistic form it recreates different types of reality. Because of this, the special role of art as a sphere of artistic imaginative perception of the world is in the fact that it can open the possibility of action, contribute to the realization of this possibility and assume the final action in the form of a result (Bremon, 2007).

\section{What are the Reasons for Radical Shifts in the Personal World Perception of a Contemporary?}

In search of an answer to the question of how the global transformations of the modern era cause radical changes in the personal ontology and world perception of our contemporaries, we pay attention to the following facts. Firstly, the fact is that globalization is accompanied by an active entry into the digital era, which significantly accelerates all kinds of interactions, changing the structure of spatial and temporal relations. One click is enough to follow serious transactions. Secondly, the digital era is a ruthless "struggle with space", pushing the boundaries, it generates an imperative-without moving in space! It is enough to 
have the distance of the outstretched hand from the computer to make a huge number of actions. Moreover, achieving success in one's own life is directly linked to having "digital skills". One can agree with the conclusion that the image of the future human without basic digital skills and information technology literacy does not reflect the spirit of the present.

Thirdly, the analysis of the digital age reveals a number of paradoxes it has generated. On the one hand, the digital environment is a real basis for further development. On the other hand, our contemporary lives in conditions of intensive information overload, which are harmful to health and have a destructive effect on the psyche. At first glance, the need for the individual as a carrier of physical energy is reduced, however, the person remains an active, practically operating being. On the one hand, the digital era creates all the conditions for "information imprisonment", on the other hand - human nature requires the natural development of his body, physiology and psychosomatics cannot be canceled! Scientists talk about the phenomenon of "interactive" loneliness and a kind of digital solipsism. However, personal intentions to successfully "make your own life" in the absence of digital skills seem untenable. The presence of "digital skills" expands the degree of freedom, even though there is a constant need for their "reassembly" for each new situation.

It is necessary to pay attention to another feature. Saturation of private space with technological innovations acts as a kind of criterion showing how a person meets the challenges of the modern global world. The man of the XXI century considers himself more successful, capable of self-realization and less vulnerable if he is more successful in mastering technological innovations. The style of consumer behavior aimed at on-line services, on-line communication, on-line education and even medicine, which tries to offer an on-line platform, is becoming more widespread. "Techno sociality", that practices the instrumental skills and their situational application, began to take a leading place in the educational process. The Internet's global claim to be a universal and self - sufficient whistleblower is obvious.

Nevertheless, the domestic philosophy, turned to the understanding of its being, is characterized today by a very high measure of reflexivity and critical assessment of the transformations of the communicative foundations of the global world, which relied on electronic forms of interaction. Under the pressure of expert assessments, it is becoming clear that live interpersonal contacts are largely reduced, cultural practices that put literature at the forefront, slide to the periphery, the expression of feelings and personal relationships takes place with the help of emoticons, symbols or pictures. Since the style of Internet communication develops spontaneously, the language of Internet users is not constrained by 
any cultural framework (Leshkevich, 2017c). Researchers argue that much of the public debate has recently been usurped by discourses that take on an antagonistic character (Abramov, Gruzdev \& Terentiev, 2016). But, despite the fact that the entry into the era of numbers is accompanied by numerous cognitive deformations, figuratively speaking, a kind of "damage", the shift towards "clip thinking" and Internet communication assigns itself the status of a cultural regulator of interactions. The risk zone is that the mode of interactive interaction in the network imposes a particular picture of reality, which may not have real analogues. Internet communication broadcasts content with manipulative, advertising or propaganda purposes, putting pressure on the psyche, consciousness and will of people. Precisely manipulation is lauded as the greatest evil of the XXI century.

\section{Conclusion}

The analysis allows us to come to the following conclusions. Firstly, national philosophy has a special paradigm. It includes a sense of past, present and future, shows a personal perspective and a continuous history of thought, an intellectual biography and meaningful priorities. The system of meanings and programs contained in it is steadily constituted in society and culture, providing "repetition of evidences", i.e. regular reproduction and self-identity. There is a kind of recognition and identification of kinship. It is the diversity of national types of philosophies that incorporate the system of universal values makes the social capital of mankind.

Secondly, national philosophy appears as a kind of "cosmo-psycho-logos" (Gachev, 1988). It is autonomous, but incorporates the genetic memory of the nation, and the special socio-historical conditions of its existence, and psycho-mental attitudes with "accommodating their landscape". The national things are dressed in a motley "institutional shirt", contributing to the preservation of successful adaptation in given conditions and circumstances.

Thirdly, a significant conceptual increment, in our opinion, will be an attempt to "big synthesis" of different worldviews to recreate a holistic image of the modern global world. This "great synthesis", combining emotional and rational, ideological and practical, should be aimed at the embodiment of truly human values. The presence of national types of worldview is a condition of social dialogue, the basis of partnership and intellectual communication. Reflecting the peculiarities of human existence, exploring the complex socio-cultural reality, the national type of philosophy contributes to the treasury of universal culture. 
Fourthly, despite the fact that the phenomenon of philosophy as a form of social consciousness aimed at understanding the world as a whole, and therefore is international, the real representativeness of the life programs of contemporaries in the conditions of complexity and uncertainty of the modern era acquire the focus of national philosophies. They directly affect the formation of individual self-consciousness, and are manifested in the life space of the individual. It is not by chance that the remarkable title of the past XXIV World Philosophical Congress "To learn to be a man" was intended to identify the vital priorities and value orientations of modern existence, showing how the national becomes universal, as "thought obedient to the voice of being gives him the word..." (Heidegger, 1993).

The question is whether human life is reduced to the development of rapidly developing technologies? A thinking person will not hesitate to give a negative answer. Researchers believe technologies train only operational skills, and the Internet-messages could only be assigned to pre-rational - lower, border level of consciousness. At the same time, a thinking person needs to constantly "unpack" personal meanings of existence. For him, self-realization, depth and freedom of human communication, being with the prospect of choice and self-incarnate existence are important.

\section{REFERENCES}

1. Abasov, K. K. (2015). National idea and common sense. The problem of Russian selfconciosness: historical memory of people. Moscow-Makhachkala, Publishing house «elta-Press».

2. Abramov, R., Gruzdev, I., \& Terentiev, E. (2016). Worry and enthusiasm in discourses about academic world: international and Russian contexts Journal club. Journal club Intelros «NLO». URL: http://www.intelros.ru/readroom/nlo/1382016/30001-trevoga-i-entuziazm-v-diskursah-ob-akademicheskom-miremezhdunarodnyy-i-rossiyskiy

3. Barlibaeva, G. (2018). Philosophical ethics of Kazakhs. Almaty: Institute of philosophy, political science and religious studies KN MON PK.

4. Berdyaev, N. A. (2007). Faith of Russia. Moscow: Eksmo.

5. Bilalov, M. I. (2012). Epistemological analysis of the Islamic culture of the South of Russia. Humanities of the south of Russia, 1, 91-100.

6. Bremon, K. (2007). Logics of narrative possibilities. The art of measuring: methods of exact sciences and semiotics. Moscow: LKI.

7. Chumakov, A. N. (2014). Globalization: contours of the whole world. Moscow: Prospekt. 
8. Gachev, G. (1988). National image of the world. Moscow: Sovietskii pisatel.

9. Heidegger, M. (1993). Time and Being. Articles and speeches. Moscow: Republic.

10. Leshkevich, T. G. (2011). Globalization and glocalization: PRO and CONTRO. Scientific thought of Caucasus, 3, 7-13. Rostov-on-Don: Publishing house SKNTS VSH OF SFU

11. Leshkevich, T. G (2017a). Prospects of human being and technological turn of modern science. 4th International Multidisciplinary Scientific Conference on Social Sciences and Arts SGEM, 2, 559-564.

12. Leshkevich, T. G. (2017b). Global modern and new understanding of subjectness. Globalization age. Volgograd: Publishing house Uchitel.

13. Leshkevich, T. G. (2017c). Philosophical meaning of modern transformations of education. Proceedings of the 2017 3rd International Conference on Arts, Design and Contemporary Education (ICADCE 2017). Advances in Social Science, Education and Humanities Research, 144, 651-653.

14. Mainzer, K. (2007). Thinking of Complexity: the Computational Dynamics of Matter, Mind and Mankind. New York: Springer.

15. Plekhanov, G. V. (1956). Selected philosophical works. Moscow: Gos. Polite. Lit.

16. Ricker, P. (2008). I am myself like another. Moscow: Izdatelstvo gumanitarnoi literaturi.

17. Robertson, R. (1995). Glocalization: Time-pace and HomogeneityHeterogeneity. Global Modernities, 1, 25-44.

\section{SOBRE OS AUTORES:}

\section{Tatiana G. Leshkevich}

Doctor of Philosophy, Professor, Academy of Psychology and Educational Sciences, Southern Federal University, Rostov-on-Don, Russia. E-mail: Leshkevicht@ mail.ru

(iD) http://orcid.org/0000-0002-8623-3854

\section{Marina A. Nikulina}

$\mathrm{PhD}$ in Philosophy, Associate Professor, Rostov Institute (Branch), All-Russian State University of Justice (Russian Law Academy of the Ministry of Justice of Russia), Rostov-onDon, Russia. E-mail: nikulina_marina@mail.ru

iD http://orcid.org/0000-0002-0689-7010 


\section{Bika B. Dzhamalova}

Doctor of Education, Professor, North Caucasian Institute (Branch), All-Russian State University of Justice (Russian Law Academy of the Ministry of Justice of Russia), Makhachkala, Russia. E-mail: uk-ski_vguy@mail.ru

(iD http://orcid.org/0000-0001-5885-3274

\section{Pari G. Shuaipova}

$\mathrm{PhD}$ in Law, Associate Professor, Rostov Institute (Branch), All-Russian State University of Justice (Russian Law Academy of the Ministry of Justice of Russia), Rostov-on-Don, Russia. E-mail: shuaypova67@mail.ru

iD http://orcid.org/0000-0002-4235-0311 